DIMENSI, VOL. 7, NO. $1: 121-146$

MARET 2018

ISSN: 2085-9996

\title{
KEPEMIMPINAN OTOKRATIS, LINGKUNGAN KERJA, KONFLIK KERJA, DAN STRES KERJA KARYAWAN PT. BINTAN BERSATU APPAREL BATAM
}

\author{
OTOCRATIC LEADERSHIP, JOB ENVIRONMENT, JOB CONFLICT, AND EMPLOYEE \\ JOB STRESS OF PT. BINTAN BERSATU APPAERL BATAM
}

\author{
Endiet Jaloe Prasetiyo ${ }^{1}$, Sri Langgeng Ratnasari ${ }^{2}$ \\ Program Studi Magister Manajemen Program Pascasarjana Universitas Riau Kepulauan \\ sarisucahyo@yahoo.com
}

\begin{abstract}
Abstrak
Penelitian ini bertujuan untuk menganalisis pengaruh kepemimpinan otokratis, lingkungan kerja dan konflik stres karyawan PT. Bintan Bersatu Apparel Batam. Penelitian ini menggunakan data kuantitatif yang berasal dari sumber primer yang telah dikumpulkan melalui kuesioner. Teknik pengumpulan data yang digunakan adalah Quota sampling. Metode analisis data yang digunakan adalah pengujian instrumen yang dilakukan dengan menguji validitas dan reliabilitas, sedangkan teknik analisis data yang digunakan adalah metode analisis deskriptif, analisis regresi linier berganda, dan pengujian hipotesis. Hasilnya menunjukkan bahwa dalam kepemimpinan otokratik parsial dan efek negatif -1,483 secara signifikan sebesar 0,139 untuk menekankan karyawan. Efek lingkungan kerja positif sebesar 2,170 dan 0,031 mengalami stres secara signifikan oleh karyawan. Variabel konflik berpengaruh positif signifikan pada 5,888 dan 0,000. Hasil pengujian secara simultan berpengaruh signifikan terhadap stres karyawan PT. Bintan Bersatu Apparel Batam.
\end{abstract}

Kata kunci: Kepemimpinan Autokratik, Lingkungan Kerja, Konflik, Stress Kerja

\begin{abstract}
This study aimed to analyze the influence of autocratic leadership, work environment and conflict on employee stress PT. Batam Bintan Bersatu Appare Batam. This study uses quantitative data derived from primary sources that have been collected through questionnaires. Data collection techniques used is Quota sampling. Data analysis method used was testing instruments made by testing the validity and reliability, while data analysis technique used is descriptive analysis method, multiple linear regression analysis, and hypothesis testing. The results showed that in partial autocratic leadership and the negative effect of -1.483 significantly by 0,139 to stress the employee. Work environment positive effect amounting to 2,170 and 0,031 to stress significantly by the employee. Variable conflict positive effect significant at 5.888 and 0.000 . The test results are simultaneously significant effect on employee stress PT Bintan Bersatu Apparel Batam.
\end{abstract}

Keywords: Autocratic Leadership, Work Environment, Conflict, Job Stress

\section{PENDAHULUAN}

Bisnis dewasa ini tumbuh dan berkembang dengan sangat dinamis serta memerlukan sistem manajemen yang efektif, artinya dapat dengan mudah menyesuaikan diri serta mengakomodasikan setiap perubahan baik yang sedang dan telah terjadi dengan cepat, tepat dan terarah serta dengan biaya yang murah. Kelangsungan hidup dan pertumbuhan dari suatu organisasi bukan hanya ditentukan dari keberhasilan dalam mengelola keuangan yang 
berdasarkan pada kekuatan modal atau uang semata, tetapi juga ditentukan dari keberhasilannya mengelola sumber daya manusia, seperti penyesuaian gaya kepemimpinan, pengelolaan lingkungan kerja, manajemen konflik dan stres kerja.

Perusahaan multinasional memiliki ketidakpastian yang cukup tinggi, yaitu lingkungan bisnis yang global, struktur perusahaan yang berubah-ubah, dan dibebani target yang cukup tinggi. Dampaknya para manajer ataupun supervisor yang mengalami stres secara langsung maupun tidak langsung akan mempengaruhi bawahannya jika tidak dapat mengendalikan diri.

Latar belakang pemimpin yang berasal dari beberapa negara juga kerap menjadi perhatian tersendiri bagi pekerja. Hal ini tercermin dari penggunaan bahasa yang kurang pas dalam memberikan instruksi kerja. Beberapa waktu pemimpin berusaha untuk mengerti dan mengucapkan Bahasa Indonesia, namun mereka juga dapat melakukan kesalahan karena terbatasnya pengetahuan pemimpin terhadap Bahasa Indonesia yang menyebabkan kesalahan pengertian kepada pekerja.

Dalam pelaksanaan aktifitas pekerjaan masih ditemukan pemimpin menerapkan kepemimpinan otokratis yang menganggap secara teori dirinyalah yang paling mengerti pekerjaan yang harus dilakukan, sementara dalam prakteknya pemimpin tersebut tidaklah dapat melaksanakan pekerjaan sesuai teorinya. Kesulitan-kesulitan yang dialami oleh pekerja tidak menjadi perhatian bagi pemimpin tersebut.

Dengan gaya memimpin otokratis seperti itu, banyak pekerja yang merasa tidak nyaman dikarenakan sikap pemimpin yang dipandang terlalu arogan dan tidak mau mendengarkan keluhan, pertanyaan maupun saran dari pekerja sehingga dalam kurun waktu tertentu pekerja dapat mengalami stres kerja.

Kondisi lingkungan kerja yang cukup panas, kebisingan yang ditimbulkan oleh mesinmesin produksi, ketatnya pengawasan yang dilakukan oleh leader maupun supervisor membuat pekerja merasa tidak nyaman yang pada akhirnya dapat memicu terjadinya stres kerja. Beban kerja yang dirasakan terlalu berat, waktu kerja yang mendesak, pengawasan kinerja yang tinggi juga merupakan salah satu pemicu stres kerja di lingkungan pekerjaan.

Tanpa disadari terkadang terjadi salah pengertian ataupun kesalahan dalm ucapan dapat memicu terjadinya konflik kerja sehingga pekerja merasa tidak dihargai oleh atasan 
ataupun teman sekerja, perbedaan pandangan antara pekerja dengan perusahaan, kelelahan kerja hingga permasalahan pribadi yang dapat memicu stress kerja pekerja.

Stres juga dapat mempengaruhi emosi, proses berpikir dan kondisi seseorang. Jika seseorang atau pekerja yang mengalami stres yang terlalu berat maka akan dapat mengganggu kemampuan pekerja tersebut untuk menghadapi lingkungan dan pekerjaan yang dilakukannya. Mengingat setiap pekerjaan memiliki kondisi stres yang berbeda-beda maka sumber daya manusia merupakan ujung tombak terlaksananya tujuan dari perusahaan harus dapat melaksanakan kegiatannya secara efektif dan efisien.

Kepemimpinan Otokratis, Lingkungan Kerja dan Konflik secara bersamaan juga terjadi di PT. Bintan Bersatu Apparel Batam, ketiga hal tersebut terjadi karena merupakan suatu komponen yang tidak dapat terpisahkan dalam sebuah organisasi yang pada akhirnya dapat memicu stres kerja pada pekerja dan akan berdampak pada produktivitas, hasil kerja maupun kinerja secara keseluruhan seperti kurang konsentrasi sehingga memperlambat proses produksi, mangkir dan tingkat kecelakaan kerja dan ketidakhadiran dikarenakan sakit yang cukup tinggi sesuai dengan kenyataan yang ditemukan.

Berdasarkan indikasi yang diperoleh dari observasi stres kerja terjadi pada pekerja yang bekerja di PT. Bintan Bersatu Apparel Batam. Karyawan PT. Bintan Bersatu Apparel Batam sebanyak 807 orang dengan kapasitas produksi yang harus mencapai target 350.000 lembar pakaian jadi setiap bulannya menjadikan stres kerja sebagai bagian yang tidak dapat dipisahkan dari aktifitas pekerjaan sehari-hari.

PT. Bintan Bersatu Apparel Batam merupakan salah satu perusahaan yang bergerak dibidang garmen khususnya produksi pakaian jadi yang ada di Kota Batam. Saat ini PT. Bintan Bersatu Apparel Batam merupakan perusahaan rekan kerja strategis bagi merk-merk ternama seperti Adidas dan Puma. Standar kualitas yang tinggi sangat diharapkan oleh pelanggan dikarenakan produk yang dihasilkan merupakan komoditas ekspor untuk pangsa pasar luar negeri, maka tuntutan untuk memiliki sumber daya manusia yang berkompeten, memiliki komitmen tinggi dan minim stres demi tercapainya tujuan organisasi merupakan syarat mutlak bagi kelangsungan hidup organisasi dan kepercayaan pelanggan. 
Berdasarkan latar belakang di atas, penelitian ini bertujuan untuk mengetahui pengaruh kepemimpinan otokratis, lingkungan kerja dan konflik baik secara parsial maupun secara simultan terhadap terhadap stress kerja di PT. Bintan Bersatu Apparel Batam. Hasil penelitian diharapkan mampu memberikan manfaat bagi pihak-pihak terkait untuk mengetahui besarnya pengaruh kepemimpinan otokratis, lingkungan kerja dan konflik dan berkontribusi secara positif terhadap pengembangan ilmu pengetahuan khususnya bidang manajemen sumber daya manusia serta kesehatan dan keselamatan kerja.

Gaya kepemimpinan adalah proses dalam mengarahkan dan mempengaruhi para anggota dalam melakukan berbagai aktivitas di suatu organisasi, pemimpin menggunakan pengaruhnya untuk memperjelas tujuan organisasi para bawahannya, memotivasi mereka untuk mencapai tujuan dan membantu menciptakan suasana kerja agar para karyawan bisa produktif dalam bekerja, (Walsa dan Ratnasari, 2016).

Arifin (2013) menyebutkan bahwa seorang pemimpin yang otokratis memiliki ciri-ciri dalam kepemimpinannya, seperti: menganggap organisasi sebagai milik pribadi, mengidentifikasikan tujuan pribadi sebagai alat semata-mata, tidak mau menerima kritik, saran dan pendapat, terlalu tergantung kepada kekuasaan formilnya, dalam tindakan pergerakannya sering mempergunakan pendekatan yang mengandung unsur pemaksaan dan punitif (bersifat menghukum).

Menurut Waluyo (2012) Lingkungan kerja dapat mempengaruhi emosional karyawan. Jika karyawan menyenangi lingkungan kerja di tempat dia bekerja, maka karyawan tersebut akan betah di tempat kerjanya, melakukan aktivitasnya sehingga waktu kerja dipergunakan secara efektif. Lingkungan kerja adalah segala sesuatu yang ada disekitar para karyawan dan dapat mempengaruhi dirinya dalam menjalankan tugas-tugas yang dibebankan. Misalnya kebersihan, musik dan lain-lain.

Menurut Sunyoto (2013) konflik adalah ketidaksetujuan antara dua atau lebih anggota organisasi atau kelompok-kelompok dalam organisasi yang timbul karena meraka harus menggunakan sumber daya yang langka secara bersama-sama, atau menjalankan kegiatan bersama-sama atau karena mereka mempunyai status, tujuan, nilai-nilai dan persepsi yang berbeda. 
Stres adalah kondisi dinamis di mana seseorang dihadapkan pada suatu peluang, tuntutan, atau sumber daya yang terkait dengan keinginan orang tersebut serta hasilnya dipandang tidak pasti dan penting. Stres berkaitan dengan tuntutan/ demand dan sumber daya/ resource. Tuntutan merupakan tanggung jawab, tekanan, kewajiban atau ketidakpastian yang dihadapi seseorang di tempat kerja. Sumber daya adalah segala sesuatu atau benda-benda yang berada dalam kendali seseorang yang dapat digunakan untuk memenuhi tuntutan tersebut (Sunyoto, 2013).

Sutanto dan Mogi (2016) dalam penelitiannya untuk mengetahui apakah work family conflict berpengaruh terhadap stres kerja dan kinerja pekerja di restoran The Duck King Imperial Chef Galaxy Mall Surabaya. Penelitian tersebut merupakan penelitian konklusif. Teknik Analisa yang digunakan dalam penelitian ini adalah partial least square (PLS). Hasil analisa data menunjukkan bahwa work family conflict berpengaruh negatif dan signifikan terhadap kinerja pekerja dan berpengaruh positif dan signifikan terhadap stres kerja. Sedangkan stres kerja berpengaruh positif dan tidak signifikan terhadap kinerja pekerja, sehingga stres kerja terbukti tidak memberikan pengaruh yang buruk dan signifikan terhadap kinerja pekerja di restoran The Duck King Imperial Chef Galaxy Mall Surabaya.

Pratiwi dan Wahyuningtyas (2015), dalam penelitiannya untuk mengetahui pengaruh lingkungan kerja fisik terhadap stres kerja karyawan PT Krakatau Steel Persero (Tbk) Divisi CRM. Hasil dalam penelitian ini menunjukkan bahwa lingkungan kerja fisik berpengaruh secara signifikan terhadap stres kerja karyawan pabrik Cold Rolling Mill PT. Krakatau Steel (Persero) Tbk karena nilai t hitung > ttabel, sehingga H0 ditolak dan H1 diterima. Besar pengaruh lingkungan kerja fisik terhadap stres kerja sebesar 32,71\% sedangkan sisanya sebesar 67,29\% dipengaruhi oleh faktor lain. Lingkungan kerja fisik dan stres kerja karyawan pabrik Cold Rolling Mill PT Krakatau Steel Persero (Tbk) termasuk dalam kategori baik.

Bahua (2014) dalam penelitiannya untuk mengetahui pengaruh lingkungan kerja terhadap stres kerja karyawan pada PT Bank Sulut cabang Gorontalo. Dari hasil penelitian dan analisis data, persamaan regresi dihasilkan yakni $\hat{Y}=54,415+0,479 X$, dengan nilai determinasi (r2)=38,2\% yang menunjukkan presentase pengaruh yang diberikan variabel $\mathrm{X}$ terhadap variabel Y, sedangkan sisa presentase sebesar 61,8\%, dipengaruhi oleh faktor lain yang tidak 
diteliti dalam penelitian ini. Dengan demikian hasil dari penelitian ini terdapat pengaruh yang signifikan dari Lingkungan Kerja terhadap Stres kerja karyawan PT. Bank Sulut Cabang Gorontalo.

Dewa dan Utama (2014), dalam penelitiannya untuk mengetahui pengaruh komunikasi, kepemimpinan dan lingkungan kerja terhadap stres kerja pegawai pada PD Pasar Kota Singaraja Unit Pasar Anyar. Regresi berganda digunakan untuk menyelesaikan masalah penelitian ini. Komunikasi, kepemimpinan dan lingkungan kerja secara simultan berpengaruh signifikan terhadap stres kerja karyawan pada PD Pasar Kota Singaraja Unit Pasar Anyar Singaraja - Bali dengan nilai $\mathrm{F}$ hitung $=118,594$ sig =0,00. Komunikasi, kepemimpinan dan lingkungan kerja secara parsial berpengaruh signifikan terhadap stres kerja karyawan pada PD Pasar Kota Singaraja Unit Pasar Anyar Singaraja Bali dengan nilai t hitung berturut-turut variabel komunikasi $=4,712$, variabel kepemimpinan $=7,753$, variabel lingkungan kerja $=$ 7,359. Berdasarkan hasil uji t terhadap variabel lingkungan kerja (X3) menunjukkan nilai thitung lebih besar dari ttabel maka dapat disimpulkan bahwa, lingkungan kerja secara parsial berpengaruh signifikan terhadap stres kerja pegawai pada PD Pasar Kota Singaraja Unit Pasar Anyar Singaraja Bali.

Zainudin dan Ratnasari (2015) dengan penelitian yang berjudul Pengaruh Gaya Kepemimpinan, Lingkungan Kerja, Dan Motivasi Terhadap Kinerja Guru Sekolah Dasar Kecamatan Batu Ampar Kota Batam dengan hasil penelitian sebagai berikut: Secara langsung ada pengaruh signifikan Gaya Kepemimpinan terhadap Motivasi Kerja, Secara langsung ada pengaruh signifikan Lingkungan Kerja terhadap Motivasi Kerja, Secara langsung ada pengaruh signifikan Gaya Kepemimpinan terhadap Kinerja, Secara langsung ada pengaruh signifikan Lingkungan Kerja terhadap Kinerja, Secara langsung ada pengaruh signifikan Motivasi Kerja terhadap Kinerja, Secara tidak langsung Gaya Kepemimpinan mempuyai pengaruh signifikan terhadap Kinerja melalui Motivasi Kerja, Secara secara tidak langsung Lingkungan Kerja mempuyai pengaruh signifikan terhadap Kinerja melalui Motivasi Kerja.

Wicaksono dan Ratnasari (2017) dengan judul penelitian Determinan Komunikasi, Motivasi, Dan Lingkungan Kerja Terhadap Kinerja Karyawan Di Perusahaan Umum (Perum) Bulog Sub-Divre Kota Batam dengan hasil penelitian sebagai berikut: Komunikasi merupakan 
determinasi yang signifikan terhadap kinerja karyawan, motivasi merupakan determinasi yang signifikan terhadap kinerja karyawan, lingkungan kerja merupakan determinasi yang signifikan terhadap kinerja karyawan, dan komunikasi, motivasi, serta lingkungan kerja merupakan determinasi yang signifikan terhadap kinerja karyawan.

Ratnasari dan Sutjahjo (2017) dengan judul penelitian Pengaruh Kepemimpinan Transformasional Dan Lingkungan Kerja Terhadap Semangat Kerja Tenaga Kependidikan, dengan hasil penelitian kepemimpinan transformasional secara parsial berpengaruh tidak signifikan terhadap semangat kerja tenaga kependidikan, lingkungan kerja mempunyai pengaruh yang signifikan terhadap semangat kerja tenaga kependidikan, kepemimpinan transformasional dan lingkungan kerja berpengaruh terhadap semangat kerja tenaga kependidikan.

Han dan Netra (2013) dalam penelitiannya untuk mengetahui pengaruh konflik terhadap stres kerja karyawan pada PT Bank Rakyat Indonesia cabang Denpasar Bali. Dari hasil analisis data menggunakan analisis faktor konfirmatori (confirmatory factor analysis), analisis Structural Equation Modelling (SEM) dan evaluasi atas asumsi-asumsi SEM. Parameter estimasi untuk pengujian pengaruh konflik terhadap stres kerja menunjukkan nilai CR sebesar 5,761 yang lebih besar dari $\pm 1,96$ dan probabilitas yang lebih kecil dari 0,05 berarti konflik berpengaruh positif terhadap stres kerja di PT Bank Rakyat Indonesia Kantor Cabang Denpasar. Kedua nilai tersebut memenuhi syarat untuk penerimaan H1.

Dengan demikian maka dapat disimpulkan bahwa hipotesis 1 (H1) yang menyatakan konflik berpengaruh positif terhadap stres kerja, dapat diterima. Nilai positif menjelaskan adanya pengaruh yang searah yaitu apabila konflik meningkat maka akan diikuti oleh meningkatnya stres kerja. Hal ini berarti meningkatnya pertentangan yang dihadapi pekerja sebagai akibat adanya berbagai masalah dalam hal komunikasi, hubungan pribadi atau karena masalah struktur organisasi berpengaruh terhadap meningkatnya stres kerja karyawan PT Bank Rakyat Indonesia Kantor Cabang Denpasar.

Berdasarkan kajian teoritis yang telah dijelaskan dan untuk memudahkan pelaksanaan penelitian, paradigma penelitian atas variabel-variabel bebas yaitu kepemimpinan otokratis, 
lingkungan kerja dan konflik dianalisis untuk mengetahui pengaruhnya terhadap stress kerja dapat digambarkan dengan kerangka sebagai berikut:

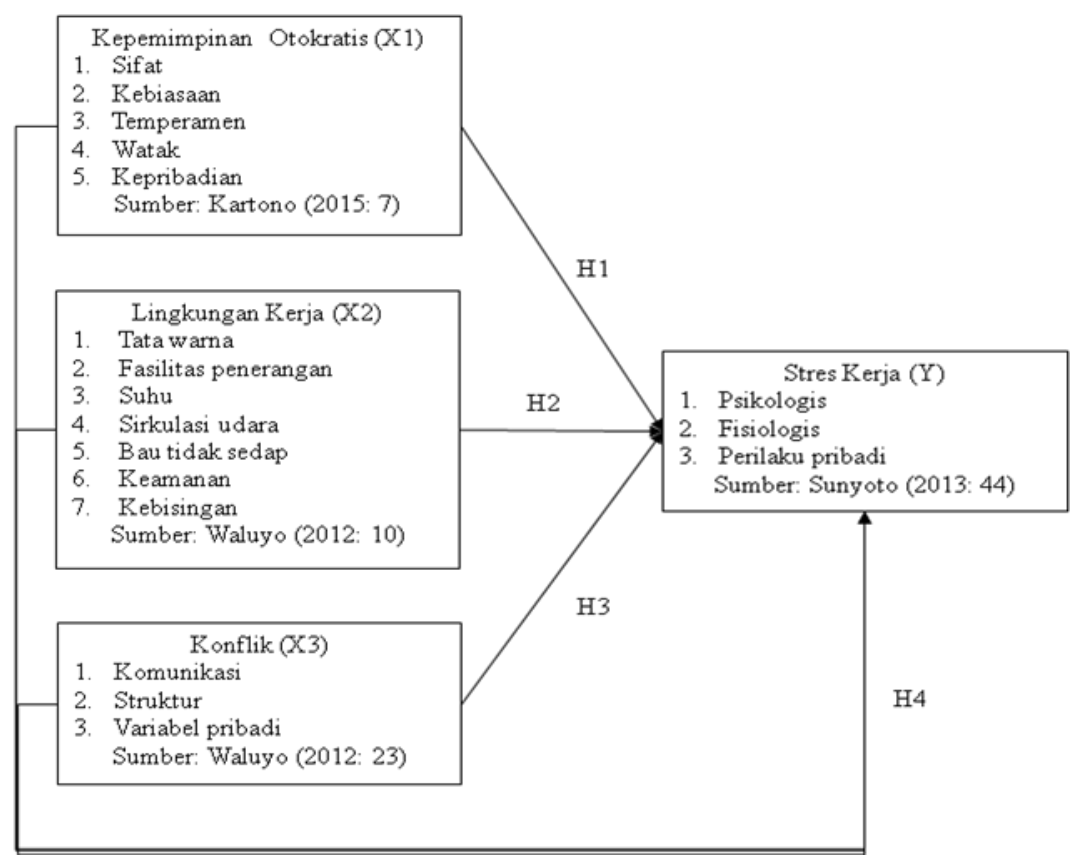

Gambar 1 Kerangka Pemikiran

Pengembangan rumusan hipotesis dari kerangkan pemikiran adalah

H1: Kepemimpinan otokratis berpengaruh positif dan signifikan terhadap stres kerja karyawan PT. Bintan Bersatu Apparel Batam.

H2: Lingkungan kerja berpengaruh positif dan signifikan terhadap stres kerja karyawan PT. Bintan Bersatu Apparel Batam.

H3: Konflik berpengaruh positif dan signifikan terhadap stres kerja karyawan PT. Bintan Bersatu Apparel Batam.

H4: Kepemimpinan Otokratis, Lingkungan Kerja dan Konflik secara simultan berpengaruh signifikan terhadap stres kerja karyawan PT. Bintan Bersatu Apparel Batam.

\section{METODOLOGI}

\section{Desain Penelitian dan Operasional Variabel}

Penelitian ini menggunakan pendekatan kuantitatif kausalitas. Sugiyono (2014), menyatakan hubungan kausal adalah hubungan yang bersifat sebab akibat. Hubungan kausal 
yang meneliti bagaimana pengaruh variabel independen terhadap variabel dependen. Sesuai dengan rumusan masalah yang telah dikemukakan bahwa penelitian ini bertujuan untuk mengetahui pengaruh variabel independen, yaitu kepemimpinan otokratis (X1), lingkungan kerja (X2) dan konflik (X3) terhadap variabel dependen, yaitu stress (Y) di PT Bintan Bersatu Apparel Batam dengan operasional variabel sebagai berikut.

\section{Tabel 1 Operasional Variabel}

\begin{tabular}{|c|c|c|c|c|}
\hline No & Variabel & Konsep Variabel & Indikator Data & Skala \\
\hline 1 & $\begin{array}{c}\text { Kepemimpinan } \\
\text { Otokratis (X1) }\end{array}$ & $\begin{array}{l}\text { Kekuasaaan atau wewenang, sebagian besar mutlak } \\
\text { tetap berada pada pimpinan atau kalau pimpinan itu } \\
\text { menganut sistem sentralisasi wewenang. } \\
\text { Pengambilan keputusan dan kebijakan hanya } \\
\text { ditetapkan sendiri oleh pemimpin, bawahan tidak } \\
\text { diikutsertakan untuk memberikan saran, ide, dan } \\
\text { pertimbangan dalam proses pengambilan } \\
\text { keputusan. Falsafah pimpinan ialah "bawahan } \\
\text { adalah untuk pemimpin/ atasan". Bawahan hanya } \\
\text { bertugas sebagai pelaksana keputusan yang telah } \\
\text { ditetapkan pimpinan. }\end{array}$ & $\begin{array}{l}\text { 1. Sifat } \\
\text { 2. Kebiasaan } \\
\text { 3. Temperamen } \\
\text { 4. Watak } \\
\text { 5. Kepribadian } \\
\text { (Kartono, 2015: 7) }\end{array}$ & Likert \\
\hline 2 & $\begin{array}{c}\text { Lingkungan } \\
\text { Kerja (X2) }\end{array}$ & $\begin{array}{l}\text { Lingkungan kerja adalah segala sesuatu yang ada } \\
\text { disekitar para pekerja dan dapat mempengaruhi } \\
\text { dirinya dalam menjalankan tugas-tugas yang } \\
\text { dibebankan. Misalnya kebersihan, musik dan lain- } \\
\text { lain. }\end{array}$ & $\begin{array}{l}\text { 1. Tata ruang } \\
\text { 2. Fasilitas } \\
\text { penerangan } \\
\text { 3. Suhu } \\
\text { 4. Pertukaran } \\
\text { udara } \\
\text { 5. Kebersihan } \\
\text { 6. Keamanan } \\
\text { 7. Kebisingan } \\
\text { (Waluyo, 2012: } \\
\text { 10) }\end{array}$ & Likert \\
\hline 3 & Konflik (X3) & $\begin{array}{l}\text { Konflik adalah ketidaksetujuan antara dua atau lebih } \\
\text { anggota organisasi atau kelompok-kelompok dalam } \\
\text { organisasi yang timbul karena mereka harus } \\
\text { menggunakan sumber daya yang langka secara } \\
\text { bersama-sama, atau menjalankan kegiatan bersama- } \\
\text { sama atau karena mereka mempunyai status, } \\
\text { tujuan, nilai-nilai dan persepsi yang berbeda. }\end{array}$ & $\begin{array}{l}\text { 1. Komunikasi } \\
\text { 2. Struktur } \\
\text { 3. Variabel } \\
\text { pribadi } \\
\text { (Waluyo, 2012: } \\
\text { 23) }\end{array}$ & Likert \\
\hline
\end{tabular}




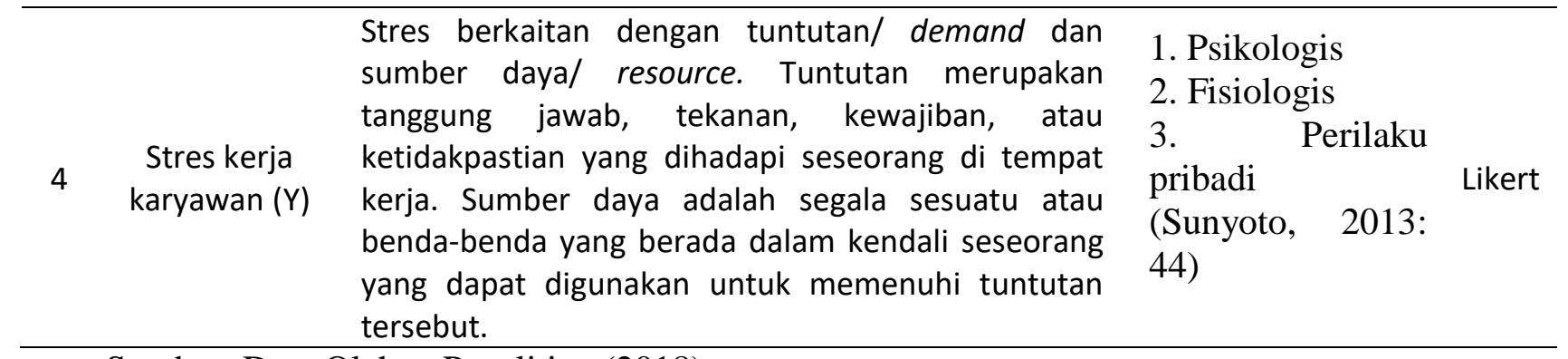

Sumber: Data Olahan Penelitian (2018)

\section{Populasi dan Sampel}

Populasi adalah wilayah generalisasi yang terdiri atas obyek/subyek yang mempunyai kualitas dan karakteristik tertentu yang ditetapkan oleh peneliti untuk dipelajari dan kemudian ditarik kesimpulannya (Sugiyono, 2014). Populasi dalam penelitian ini adalah semua karyawan PT. Bintan Bersatu Apparel Batam yang berjumlah 807 orang sehingga kesimpulan hasil penelitian adalah menurut pendapat karyawan PT. Bintan Bersatu Apparel Batam. Pemilihan populasi yang terpusat pada karyawan disesuaikan dengan indikator yang digunakan. Pengambilan sampel yang representatif ditetapkan melalui teknik non-probability sampling dengan sistem incidental sampling. Rumus Slovin digunakan untuk menentukan jumlah sampel sehingga dari jumlah populasi 807 karyawan diperoleh total sampel 283 karyawan yang akan menjadi responden.

\section{Teknik Pengumpulan dan Analisis Data}

Pengumpulan data merupakan tahap yang penting dalam penelitian karena berdasarkan data yang terkumpul akan dilakukan analisis sebelum akhirnya ditarik kesimpulan. Teknik pengumpulan data dalam penelitian ini menggunakan angket (kuesioner) yang akan disebar kepada seluruh responden dengan bentuk kuesioner tertutup karena pilihan jawaban sudah disediakan dengan bantuan alat pengukuran skala Likert, yaitu memberi skor pada masingmasing pernyataan sesuai indikator variabel penelitian seperti Tabel 2. 
Tabel 2 Skala Likert

\begin{tabular}{clcc}
\hline No & \multicolumn{1}{c}{ Jawaban } & Kode & Skor \\
\hline 1 & Sangat Setuju & SS & 5 \\
2 & Setuju & S & 4 \\
3 & Ragu-Ragu & RG & 3 \\
4 & Tidak Setuju & TS & 2 \\
5 & Sangat Tidak Setuju & STS & 1 \\
\hline
\end{tabular}

Sumber: Sugiyono (2014)

Metode analisis data diawali dengan uji kualitas instrumen yaitu uji validitas dan uji reliabilitas. Hasil penelitian dikatakan valid apabila terdapat kesamaan antara data yang terkumpul dengan data yang sesungguhnya terjadi pada obyek yang diteliti, bila koefisien korelasi sama dengan 0,30 atau lebih (paling kecil 0,30), maka butir instrumen dinyatakan valid (Sugiyono, 2014). Penelitian ini menguji validitas konstruk (construct validity) dari variabelnya dengan menggunakan teknik Pearson Product Moment.

$$
r=\frac{\mathrm{n}(\mathrm{LXY})-(\mathrm{LX}) \cdot(\mathrm{YY})}{\sqrt{\left\{\mathrm{n} \cdot \sum \mathrm{X}^{2}-\left(\sum \mathrm{X}\right)^{2}\right\} \cdot\left[\mathrm{n} \cdot \sum \mathrm{Y}^{2}-\left(\sum \mathrm{Y}\right)^{2}\right\}}}
$$

\section{Rumus 1 Pearson Product Moment} Sumber: Sanusi (2014)

Pengujian reliabilitas adalah berkaitan dengan masalah adanya kepercayaan terhadap instrumen. Suatu instrumen dapat memiliki tingkat kepercayaan yang tinggi (konsisten) jika hasil dari pengujian instrumen tersebut menunjukkan hasil yang tetap. Pengujian reliabilitas instrumen dilakukan dengan internal consistency dengan teknik belah dua (split half) yang dianalisis dengan rumus Spearman Brown (Sugiyono, 2014). Sanusi (2014) juga menyatakan metode yang sama untuk menghitung reliabilitas dan selanjutnya dijadikan acuan dalam penelitian ini, yang diformulasikan dengan menggunakan rumus sebagai berikut. $\mathrm{r}_{s b}=\frac{2 r_{p m}}{1+r_{p m}}$

\section{Rumus 2 Spearman Brown}

Sumber: Sanusi (2014)

Uji asumsi klasik merupakan prasyarat yang harus dilakukan pada penelitian yang menggunakan metode statistik parametris. Penelitian ini mengembangkan tiga uji yaitu uji normalitas, uji multikolinearitas dan uji heteroskedastisitas. 
Persamaan regresi adalah persamaan yang mendefinisikan sifat hubungan antara dua atau lebih variabel. Penelitian ini menggunakan bantuan program software SPSS (Statistical Product and Service Solutions) versi 24 dalam menguji persamaan regresi.

$$
\mathrm{Y}=\mathrm{a}+\mathrm{b}_{1} \mathrm{X}_{1}+\mathrm{b}_{2} \mathrm{X}_{2}+\mathrm{b}_{3} \mathrm{X}_{3}+\mathrm{e}
$$

\section{Rumus 3 Regresi Linear Berganda}

Sumber: Sanusi (2014)

Rangkaian uji hipotesis dikembangkan untuk menunjukkan seberapa jauh pengaruh variabel independen dalam menerangkan variasi variabel dependen baik secara parsial maupun simultan melalui uji t dan uji $\mathrm{F}$, sedangkan besarnya tingkat pengaruh variabel independen terhadap variabel dependen diuji melalui analisis koefisien determinasi $\left(\mathrm{R}^{2}\right)$.

\section{PEMBAHASAN}

\section{Profil Responden}

Penelitian ini menggunakan dan informasi yang diperoleh dan diolah merupakan hasil dari distribusi kuesioner yang telah disebar dan dikembalikan. Kuesioner telah disebar sebanyak 300 lembar dengan tingkat pengembalian 94\%. Tabel di bawah ini akan menjelaskan tingkat pengembalian kuesioner dari keseluruhan kuesioner yang disebar kepada responden, sebagai berikut.

Tabel 3 Tingkat Pengembalian Kuesioner

\begin{tabular}{lc}
\hline \multicolumn{1}{c}{ Keterangan } & Jumlah \\
\hline Jumlah sampel yang dibutuhkan & 267 lembar \\
Kuesioner yang disebar & 300 lembar \\
Kuesioner yang tidak dikembalikan & 17 lembar \\
Kuesioner yang tidak diisi & 0 lembar \\
Kuesioner yang digunakan untuk dianalisis & 283 lembar \\
\hline
\end{tabular}

Sumber: Data primer diolah (2018)

Dua ratus delapan puluh tiga lembar kuesioner yang terkumpul tidak hanya menyajikan pernyataan-pernyataan mengenai variabel yang akan diuji dan diolah dalam penelitian akan tetapi juga menampilkan identitas responden yang memberikan gambaran tentang keadaan diri responden yang berguna sebagai penunjang data. Identitas responden dalam kuesioner meliputi jenis kelamin, usia masa kerja dan pendidikan yang penyebaran datanya akan disajikan sebagai berikut. 
DIMENSI, VOL. 7, NO. $1: 121-146$

MARET 2018

ISSN: 2085-9996

Tabel 4 Profil Responden

\begin{tabular}{|c|c|c|c|c|}
\hline No & Keterangan & Klasifikasi & Jumlah (Orang) & Persentase \\
\hline \multirow[t]{3}{*}{1} & Jenis Kelamin & Pria & 77 & $27,2 \%$ \\
\hline & & Wanita & 206 & $72,8 \%$ \\
\hline & Juı & & 283 & $100 \%$ \\
\hline \multirow[t]{5}{*}{2} & Pendidikan & SMP & 32 & $11.3 \%$ \\
\hline & & SMA/SMK & 220 & $77.7 \%$ \\
\hline & & D3 & 8 & $2.8 \%$ \\
\hline & & $\mathrm{S} 1$ & 23 & $8.1 \%$ \\
\hline & Juı & & 283 & $100 \%$ \\
\hline \multirow[t]{5}{*}{3} & Usia & 18-26 tahun & 63 & $22.3 \%$ \\
\hline & & 27-35 tahun & 163 & $57.6 \%$ \\
\hline & & 36-44 tahun & 52 & $18.4 \%$ \\
\hline & & 45-53 tahun & 5 & $1.8 \%$ \\
\hline & JuI & & 283 & $100 \%$ \\
\hline \multirow[t]{3}{*}{4} & Masa Kerja & $>5$ tahun & 165 & $58,3 \%$ \\
\hline & & $\leq 5$ tahun & 118 & $41,7 \%$ \\
\hline & Juı & & 338 & $100 \%$ \\
\hline
\end{tabular}

Sumber: Data primer diolah (2018)

\section{Uji Kualitas Instrumen}

\section{Uji Validitas}

Uji validitas merupakan suatu langkah pengujian yang harus dilakukan untuk mengetahui isi dari suatu instrumen (kuesioner), tujuannya adalah untuk mengukur ketepatan instrumen (kuesioner) yang digunakan. Penelitian ini menggunakan teknik korelasi Pearson Product Moment dengan bantuan perangkat lunak SPSS versi 21. Apabila nilai koefisien korelasi dari perhitungan Pearson Product Moment atau $\mathrm{r}$ hitung $>\mathrm{r}$ tabel (untuk $\alpha=0,05$ dan derajat kebebasan $(\mathrm{dk}=\mathrm{n}-2)$ dengan nilai 0,116) maka pernyataan tersebut dinyatakan valid. Pengujian ini memiliki 3 variabel bebas yaitu Kepempimpinan Otokratis (X1), Lingkungan Kerja (X2) dan Konflik (X3) serta 1 variabel terikat yaitu Stres Kerja (Y). Hasil uji masingmasing variabel terhadap item pernyataan akan dirincikan sebagai berikut. 
Tabel 5 Hasil Uji Validitas

\begin{tabular}{|c|c|c|c|c|c|}
\hline No & Variabel & Item & r hitung & r tabel & Hasil \\
\hline 1 & \multirow{14}{*}{$\begin{array}{c}\text { Kepemimpinan } \\
\text { Otokratis } \\
\text { (X1) }\end{array}$} & X1.1 & 0,165 & 0,116 & Valid \\
\hline 2 & & $\mathrm{X} 1.2$ & 0,730 & 0,116 & Valid \\
\hline 3 & & X1.3 & 0,871 & 0,116 & Valid \\
\hline 4 & & X1.4 & 0,742 & 0,116 & Valid \\
\hline 5 & & X1.5 & 0,737 & 0,116 & Valid \\
\hline 6 & & X1.6 & 0,767 & 0,116 & Valid \\
\hline 7 & & X1.7 & 0,182 & 0,116 & Valid \\
\hline 8 & & X1.8 & 0,871 & 0,116 & Valid \\
\hline 9 & & X1.9 & 0,380 & 0,116 & Valid \\
\hline 10 & & $\mathrm{X} 1.10$ & 0,656 & 0,116 & Valid \\
\hline 11 & & X2.1 & 0,271 & 0,116 & Valid \\
\hline 12 & & X2.2 & 0,327 & 0,116 & Valid \\
\hline 13 & & X2.3 & 0,329 & 0,116 & Valid \\
\hline 14 & & X2.4 & 0,419 & 0,116 & Valid \\
\hline 15 & \multirow{10}{*}{$\begin{array}{l}\text { Lingkungan Kerja } \\
\text { (X2) }\end{array}$} & X2.5 & 0,394 & 0,116 & Valid \\
\hline 16 & & X2.6 & 0,329 & 0,116 & Valid \\
\hline 17 & & X2.7 & 0,500 & 0,116 & Valid \\
\hline 18 & & X2.8 & 0,763 & 0,116 & Valid \\
\hline 19 & & X2.9 & 0,735 & 0,116 & Valid \\
\hline 20 & & $\mathrm{X} 2.10$ & 0,611 & 0,116 & Valid \\
\hline 21 & & X3.1 & 0,608 & 0,116 & Valid \\
\hline 22 & & X3.2 & 0,493 & 0,116 & Valid \\
\hline 23 & & X3.3 & 0,642 & 0,116 & Valid \\
\hline 24 & & X3.4 & 0,539 & 0,116 & Valid \\
\hline 25 & \multirow{10}{*}{$\begin{array}{l}\text { Konflik } \\
\text { (X3) }\end{array}$} & X3.5 & 0,513 & 0,116 & Valid \\
\hline 26 & & X3.6 & 0,461 & 0,116 & Valid \\
\hline 27 & & X3.7 & 0,374 & 0,116 & Valid \\
\hline 28 & & X3.8 & 0,587 & 0,116 & Valid \\
\hline 29 & & X3.9 & 0,500 & 0,116 & Valid \\
\hline 30 & & X3.10 & 0,526 & 0,116 & Valid \\
\hline 31 & & Y.1 & 0,613 & 0,116 & Valid \\
\hline 32 & & Y.2 & 0,711 & 0,116 & Valid \\
\hline 33 & & Y.3 & 0,432 & 0,116 & Valid \\
\hline 34 & & Y.4 & 0,469 & 0,116 & Valid \\
\hline 35 & Stres Kerja & Y.5 & 0,594 & 0,116 & Valid \\
\hline 36 & \multirow[t]{5}{*}{ Karyawan (Y) } & Y.6 & 0,589 & 0,116 & Valid \\
\hline 37 & & Y.7 & 0,663 & 0,116 & Valid \\
\hline 38 & & Y.8 & 0,455 & 0,116 & Valid \\
\hline 39 & & Y.9 & 0,524 & 0,116 & Valid \\
\hline 40 & & Y.10 & 0,425 & 0,116 & Valid \\
\hline
\end{tabular}


Tabel 5 menunjukkan bahwa hasil uji validitas kepemimpinan otokratis (X1), Lingkungan Kerja (X2), Konflik (X3) dan Stres Kerja (Y) untuk semua butir pernyataan mempunyai nilai $\mathrm{r}$ hitung $>\mathrm{r}$ tabel, dengan taraf signifikan $\alpha=0,05$ dan derajat kebebasan ( $\mathrm{df}$ $=\mathrm{n}$-2) dan semua nilai $\mathrm{r}$ hitung lebih besar dari 0,30 (Sugiyono, 2014) sehingga dapat disimpulkan bahwa semua pernyataan pada 4 variabel penelitian dinyatakan valid.

\section{Uji Reliabilitas}

Uji reliabilitas bertujuan untuk mengukur kestabilan dan konsistensi dari instrument penelitian. Instrumen yang reliabel akan menghasilkan data yang dapat dipercaya. Pengujian reliabilitas dalam penelitian ini memiliki 3 variabel bebas yaitu Kepempimpinan Otokratis (X1), Lingkungan Kerja (X2) dan Konflik (X3) serta 1 variabel terikat yaitu Stres Kerja (Y) dengan menggunakan teknik Cronbach's Alpha. Hasil uji terhadap variabel dinyatakan reliabel ketika nilai alpha lebih besar dari nilai $r$ tabel pada taraf signifikan $\alpha=0,05$ dan derajat kebebasan $(\mathrm{dk}=\mathrm{n}-2)$ diperoleh hasil sebagai berikut.

Tabel 6 Hasil Uji Reliabilitas

\begin{tabular}{clccc}
\hline No & \multicolumn{1}{c}{ Variabel } & $\begin{array}{c}\text { Spearman } \\
\text { Brown }\end{array}$ & r tabel & Hasil \\
\hline 1 & Kepemimpinan Otokratis (X1) & 0,827 & 0,116 & Reliabel \\
2 & Lingkungan Kerja (X2) & 0,644 & 0,116 & Reliabel \\
3 & Konflik (X3) & 0,695 & 0,116 & Reliabel \\
4 & Stres Kerja (Y) & 0,738 & 0,116 & Reliabel \\
\hline
\end{tabular}

Sumber: Data primer diolah (2018)

Tabel 6 menunjukkan bahwa hasil uji realibilitas untuk X1 bernilai 0,827, untuk X2 bernilai 0,6444, untuk X3 bernilai 0,695 dan Y mempunyai nilai 0,738 sehingga dapat disimpulkan bahwa seluruh item memiliki nilai lebih besar dari r tabel dan dinyatakan reliabel.

\section{Uji Asumsi Klasik}

\section{Uji Normalitas}

Uji normalitas digunakan untuk mengetahui apakah nilai residu (perbedaan yang ada) yang diteliti memiliki distribusi normal sebagai salah satu syarat analisis data dengan statistik parametris yang digunakan dalam penelitian ini. Uji normalitas dilakukan secara visual dengan 
histogram dan Normal P-P Plot of Regresion Standarized Residual, serta melalui uji Kolmogorov Smirnov. Hasil pengujian disajikan sebagai berikut.

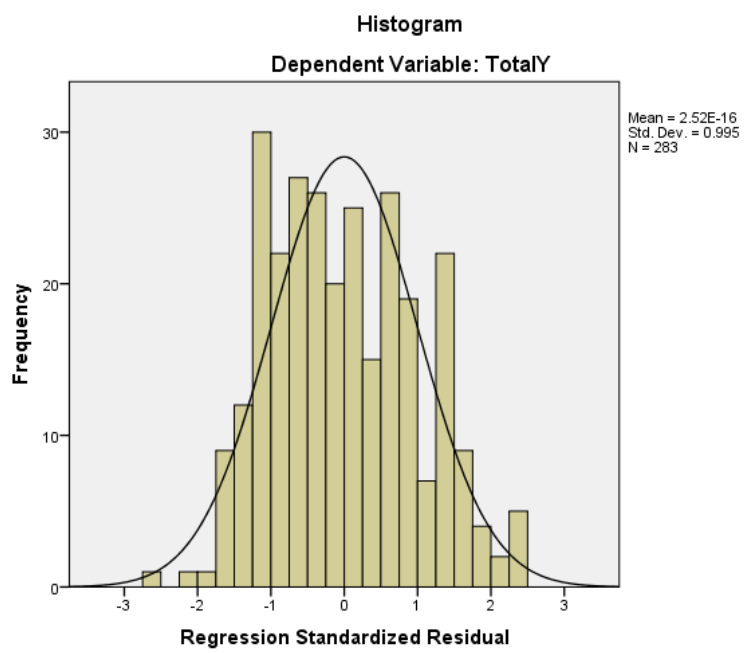

Gambar di atas memperhatikan dan membentuk pola gambar lonceng atau bell shaped maka dapat disimpulkan bahwa data memiliki distribusi normal (Wibowo, 2012).

\section{Uji Multikolineraitas}

Uji multikolinearitas bertujuan untuk menguji apakah pada model regresi ditemukan adanya korelasi antar variabel independen. Pendeteksian terhadap multikolinearitas dilakukan dengan melihat nilai Variance Inflation Factor (VIF) dari hasil regresi. Jika nilainya VIF > 10 maka terdapat gejala multikolinearitas yang tinggi (Sanusi, 2014). Hasil pengujian multikolinearitas dengan nilai VIF adalah sebagai berikut.

Tabel 7 Hasil Uji Multikolinearitas Coefficients $^{a}$

\begin{tabular}{llcr}
\hline \multicolumn{4}{c}{ Coefficients $^{a}$} \\
\multicolumn{3}{c}{ Collinearity Statistics } \\
& & Tolerance & VIF \\
\hline \multirow{2}{*}{1} & Kepemimpinan_Otokratis_X1 & .995 & 1.005 \\
& Lingkungan_Kerja_X2 & .994 & 1.006 \\
& Konflik_X3 & .997 & 1.003 \\
\hline
\end{tabular}

Sumber: Data primer diolah (2018)

Tabel 7 menunjukkan bahwa nilai VIF untuk variabel X1, X2 dan X3 masing-masing sebesar 1,005; 1,006; 1,003 sehingga dapat disimpulkan bahwa dalam model regresi tidak terdapat gejala multikolinearitas antar variabel bebas karena nilai VIF nya lebih kecil dari 10 
yang berarti bahwa semua variabel tersebut dapat digunakan sebagai variabel yang saling independen.

\section{Uji Heteroskedastisitas}

Uji heteroskedastisitas digunakan untuk mengetahui ada atau tidaknya penyimpangan asumsi klasik heteroskedastisitas yaitu adanya ketidaksamaan varian dari residual untuk semua pengamatan pada model regresi. Penelitian ini menggunakan metode Gleyser untuk menguji gejala heteroskedastisitasnya dengan hasil sebagai berikut.

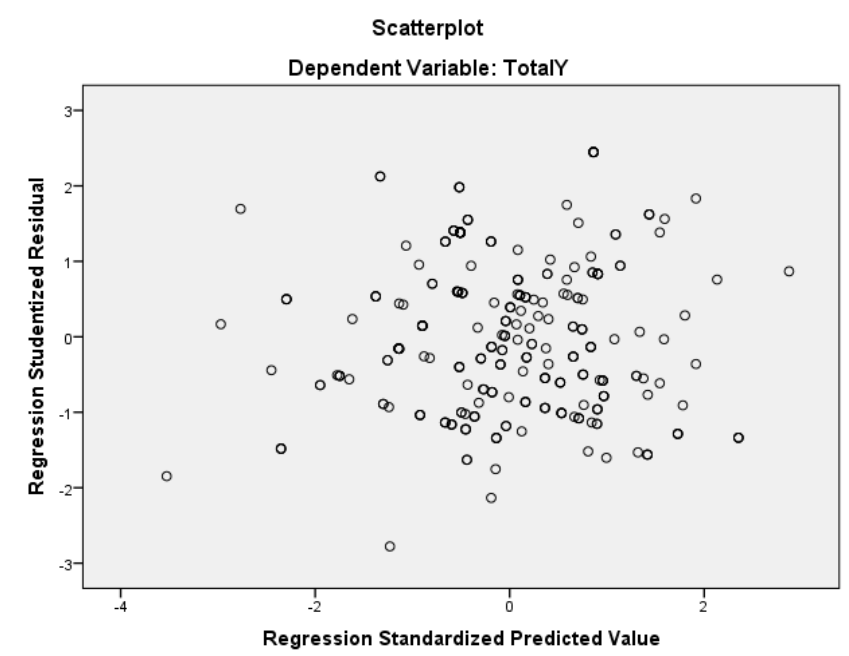

Grafik di atas memperlihatkan pola titik-titik yang menyebar tanpa membentuk suatu pola tertentu baik di bawah maupun di atas angka 0 pada sumbu $Y$ sehingga dapat disimpulkan bahwa tidak terjadi heteroskedastisitas pada model regresi.

\section{Uji Regresi Liner Berganda}

Regresi linear berganda digunakan untuk meramalkan pengaruh dari variabel-variabel bebas terhadap variabel terikat untuk membuktikan ada atau tidaknya hubungan fungsional antara variabel-variabel tersebut. Persamaan regresi dapat diketahui pada output SPSS pada tabel coefficient. 
Tabel 8 Hasil Uji Regresi Linear Berganda

Coefficients $^{a}$

\begin{tabular}{|c|c|c|c|c|c|c|}
\hline \multirow[t]{2}{*}{ Mod } & & \multicolumn{2}{|c|}{$\begin{array}{l}\text { Unstandardized } \\
\text { Coefficients }\end{array}$} & \multirow{2}{*}{$\begin{array}{l}\text { Standardize } \\
\text { d } \\
\text { Coefficients } \\
\text { Beta }\end{array}$} & \multirow[t]{2}{*}{$\mathrm{t}$} & \multirow[t]{2}{*}{ Sig. } \\
\hline & & $\mathrm{B}$ & Std. Error & & & \\
\hline \multirow{5}{*}{1} & (Constant) & 13.086 & 2.997 & & 4.367 & .000 \\
\hline & Kepemimpinan & -.065 & .044 & -.083 & -1.483 & .139 \\
\hline & Otokratis_X1 & & & & & \\
\hline & Lingkungan_Kerja_X2 & .132 & .061 & .121 & 2.170 & .031 \\
\hline & Konflik_X3 & .419 & .071 & .329 & 5.888 & .000 \\
\hline
\end{tabular}

Sumber: Data primer diolah (2018)

Berdasarkan tabel 8 dapat diperoleh persamaan regresi linear berganda sebagai berikut:

$\mathrm{Y}=13,086-0,065 \mathrm{X} 1+0,132 \mathrm{X} 2+0,419 \mathrm{X} 3+\mathrm{e}$

Penjelasan dari persamaan tersebut adalah

1. Konstan $=13,086$

Nilai konstan positif, menunjukkan pengaruh positif variabel Kepemimpinan Otokratis, Lingkungan Kerja dan variabel Konflik. Jika nilai variabel Kepemimpinan Otokratis, variabel Lingkungan Kerja dan variabel Konflik sebesar $=0$, maka nilai variabel dari Stres Kerja sebesar 13,086.

2. Kepemimpinan Otokratis $(\mathrm{X} 1)=-0,065$

Nilai ini merupakan nilai koefisien regresi variabel kepemimpinan otokratis terhadap variabel stres kerja. Koefisien bernilai negatif menunjukkan bahwa semakin tinggi nilai variabel kepemimpinan otokratis (X1) maka semakin rendah nilai variabel stres kerja, yang berarti terdapat hubungan negatif antara variabel kepemimpinan otokratis (X1) dengan variabel stres kerja (Y). Jika variabel kepemimpinan otokratis naik 1\% atau 1 poin maka variabel stres kerja akan menurun sebesar 0,001.

3. Lingkungan Kerja (X2) $=0,132$

Nilai ini merupakan nilai koefisien regresi variabel lingkungan kerja terhadap variabel stres kerja. Koefisien bernilai positif menunjukkan bahwa semakin tinggi nilai variabel lingkungan 
kerja (X2) maka semakin tinggi nilai variabel stres kerja, yang berarti terdapat hubungan positif antara variabel lingkungan kerja (X2) dengan variabel stres kerja (Y). Jika variabel lingkungan kerja naik 1\% atau 1 poin maka variabel stres kerja akan meningkat sebesar 0,132.

4. Konflik $(\mathrm{X} 3)=0,419$

Nilai ini merupakan nilai koefisien regresi variabel konflik terhadap variabel stres kerja. Koefisien bernilai positif menunjukkan bahwa semakin tinggi nilai variabel konflik (X3) maka semakin tinggi nilai variabel stres kerja, yang berarti terdapat hubungan positif antara variabel konflik (X3) dengan variabel stres kerja (Y). Jika variabel konflik naik 1\% atau 1 poin maka variabel stres kerja akan meningkat sebesar 0,419.

\section{Rancangan Uji Hipotesis}

\section{Uji t (Parsial)}

Uji t digunakan untuk mengukur apakah dalam model regresi variabel bebas secara parsial berpengaruh secara signifikan terhadap variabel terikat. Pengujian dilakukan dengan menggunakan t hitung dan tingkat signifikan.

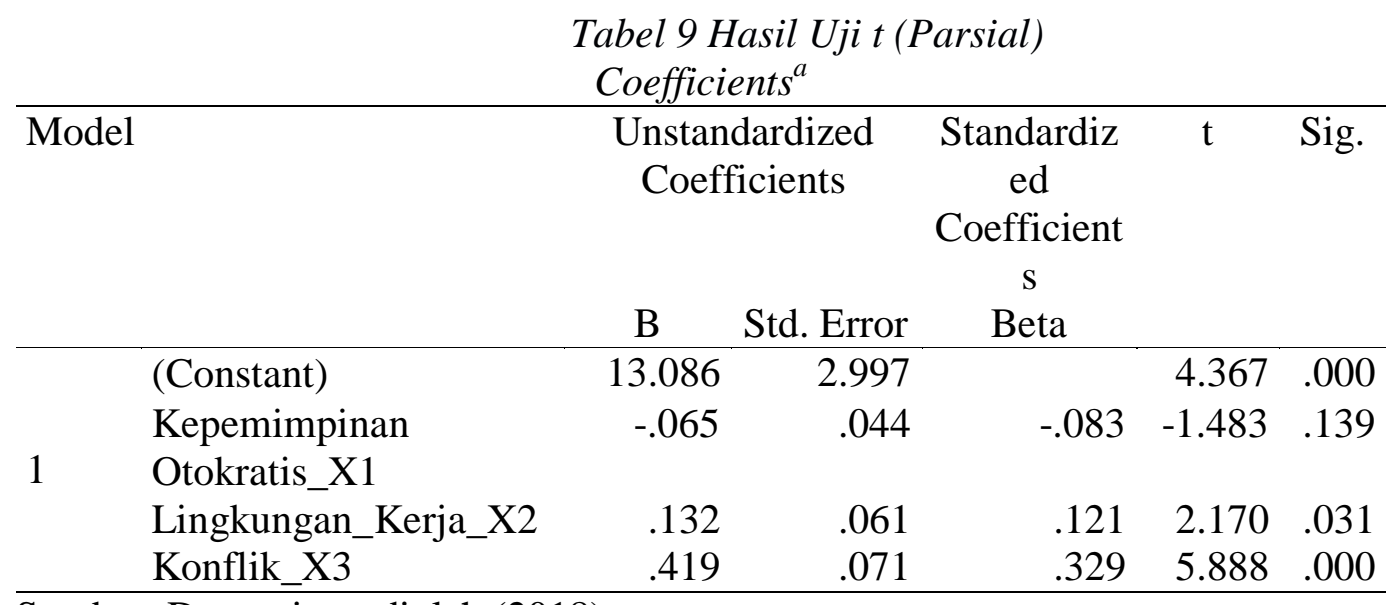

Sumber: Data primer diolah (2018)

Hasil dari Tabel 9 menunjukkan bahwa variabel kepemimpinan otokratis (X1) nilai t hitung $-1,483<\mathrm{t}$ tabel 1,968 dan nilai signifikansi 0,139>0,05 sehingga keputusan yang diambil adalah H0 diterima dan Ha ditolak. Hal ini berarti bahwa variabel kepemimpinan otokratis (X1) tidak berpengaruh secara positif dan signifikan terhadap stres kerja. 
Variabel lingkungan kerja (X2) menunjukkan hasil t hitung 2,170 > t tabel 1,968 dan nilai signifikansi 0,031 < 0,05 sehingga keputusan yang diambil adalah H0 ditolak dan H1 diterima. Hal ini berarti bahwa lingkungan kerja (X2) berpengaruh secara positif dan signifikan terhadap stres kerja.

Variabel konflik (X3) menunjukkan hasil t hitung 5,888 > t tabel 1,968 dan nilai signifikan 0,000 < 0,05 sehingga keputusan yang diambil adalah H0 ditolak dan H1 diterima. Hal ini berarti bahwa konflik (X3) berpengaruh secara positif dan signifikan terhadap stres kerja.

\section{Uji F}

Uji F digunakan untuk mengetahui apakah seluruh variabel independen secara bersamasama mempunyai pengaruh yang positif terhadap variabel dependen. Pengujian dilakukan dengan membandingkan nilai F_hitung dengan F_tabel pada derajat kesalahan 5\% dalam arti $(\alpha=0,05)$.

\begin{tabular}{|c|c|c|c|c|c|c|}
\hline & & & $\begin{array}{l}\text { el } 101 \\
\text { OVA }\end{array}$ & Hasil Uji F & & \\
\hline Model & & Sum of & $\mathrm{df}$ & Mean Square & $\mathrm{F}$ & Sig. \\
\hline & Regression & 1094.907 & 3 & 364.969 & 14.272 & $.000^{\mathrm{b}}$ \\
\hline 1 & Residual & 7134.739 & 279 & 25.573 & & \\
\hline & Total & 8229.647 & 282 & & & \\
\hline
\end{tabular}

\section{a. Dependent Variable: TotalY \\ b. Predictors: (Constant), TotalX3, TotalX1, TotalX2}

Sumber: Data primer diolah (2018)

Hasil uji F memperlihatkan nilai F sebesar 14,272 (F hitung) > 2,637 (F table) dan nilai probabilitas signifikansi sebesar 0,000 < 0,05 sehingga keputusan yang diambil adalah H0 ditolak dan Ha diterima. Hasil ini menunjukkan bahwa variabel kepemimpinan otokratis (X1), lingkungan kerja (X2) dan konflik (X3) mampu menjelaskan keragaman dari variabel terikat secara bersama-sama terhadap variabel stres kerja (Y) dan bentuk regresi linear sudah tepat.

\section{Uji Koefisien Determinasi $\left(R^{2}\right)$}

Koefisien determinasi $\left(\mathrm{R}^{2}\right)$ berfungsi menjelaskan proporsi variasi dalam variabel terikat (Y) yang dijelaskan oleh variabel bebas (lebih dari satu variabel) secara bersama-sama 
(Sanusi, 2014). Nilai koefisien determinasi adalah antara nol dan satu. Nilai ( ${ }^{2}$ ) yang kecil berarti kemampuan variabel-variabel independen (kepemimpinan otokratis, lingkungan kerja dan konflik) dalam menjelaskan variasi variabel dependen (stres kerja) amat terbatas. Begitu pula sebaliknya, nilai yang mendekati satu berarti variabel independen memberikan hampir semua informasi yang dibutuhkan untuk memprediksi variasi variabel dependen. Hasil pengujian koefisien determinasi dalam penelitian ini sebagai berikut.

Tabel 11 Hasil Uji Koefisien Determinasi Model Summary ${ }^{b}$

\begin{tabular}{lrrrr}
\hline Model & R & R Square & Adjusted R Square & Std. Error of the Estimate \\
\hline 1 & $.365^{\mathrm{a}}$ & .133 & .124 & 5.057 \\
\hline
\end{tabular}

a. Predictors: (Constant), Total_Kepemimpinan_Otokratis, Total_Lingkungan_Kerja, Total_Konflik) b. Dependent Variable: Total_Stres_Kerja Sumber: Data primer diolah (2016)

Tabel 11 memperlihatkan nilai $\mathrm{R}$ sebesar 0,365 artinya korelasi antara variabel kepemimpinan otokratis (X1), lingkungan kerja (X2) dan konflik (X3) terhadap variabel stres kerja (Y) sebesar 0,365. Hal ini berarti bahwa hubungan variabel bebas terhadap variabel terikat kurang dari 50\% dan belum mendekati 1. Hasil pengujian nilai adjusted R Square sebesar 0,124 menunjukkan bahwa hanya 12,4\% dari stres kerja yang dapat dijelaskan oleh variabel kepemimpinan otokratis, lingkungan kerja dan konflik. Sisanya sebesar 87,6\% stres kerja dipengaruhi oleh variabel-variabel lain yang tidak dijelaskan dalam penelitian ini.

\section{Pembahasan}

Berdasarkan hasil pengujian yang telah dilakukan dapat dilihat bahwa variabel kepemimpinan otokratis (X1) dengan nilai koefisien sebesar -0,065 berpengaruh negatif dan tidak signifikan terhadap stres kerja, hal ini terlihat dari nilai signifikan 0,139>0,05 (nilai alpha). Hasil uji t hitung -1,483 < t tabel 1,968 menunjukkan bahwa variabel kepemimpinan otokratis (X1) berpengaruh negatif dan tidak signifikan terhadap stres kerja.

Dewa dan Utama (2014) dalam penelitiannya menyebutkan bahwa kepemimpinan berpengaruh signifikan terhadap stres kerja namun dalam penelitian ini terlihat bahwa tidak ada signifikansi kepemimpinan otokratis (X1) dalam mempengaruhi stres kerja. Kemungkinan 
hal ini dikarenakan pada penelitian Dewa dan Utama (2014) tidak dilakukan pemisahan terhadap gaya kepemimpinan sehingga persepsi responden terhadap macam-macam gaya kepemimpinan dianggap sama.

Berdasarkan hasil pengujian yang telah dilakukan dapat dilihat bahwa variabel lingkungan kerja (X2) dengan nilai koefisien sebesar 0,132 berpengaruh positif dan signifikan terhadap stres kerja, hal ini terlihat dari nilai signifikan 0,031 < 0,05 (nilai alpha). Hasil uji t hitung 2,170 > t tabel 1,968 menunjukkan bahwa variabel lingkungan kerja (X2) berpengaruh secara positif dan signifikan terhadap stres kerja.

Bahua (2014) dalam penelitiannya menyebutkan bahwa lingkungan kerja berpengaruh signifikan terhadap stres kerja yang berarti selaras dengan penelitian ini yaitu ada signifikansi lingkungan kerja (X2) dalam mempengaruhi stres kerja. Dengan kata lain, apabila lingkungan kerja kondusif maka karyawan dapat menjalankan pekerjaan secara optimal.

Berdasarkan hasil pengujian yang telah dilakukan dapat dilihat bahwa variabel konflik (X3) dengan nilai koefisien sebesar 0,419 berpengaruh positif dan signifikan terhadap stres kerja, hal ini terlihat dari nilai signifikan 0,000 < 0,05 (nilai alpha). Hasil uji t hitung 5,888 $>\mathrm{t}$ tabel 1,968 menunjukkan bahwa variabel konflik (X3) berpengaruh secara positif dan signifikan terhadap stres kerja.

Han dan Netra (2013) dalam penelitiannya menyebutkan bahwa konflik berpengaruh positif terhadap stres kerja yang berarti selaras dengan penelitian ini yaitu ada signifikansi konflik (X3) dalam mempengaruhi stres kerja.

Hasil uji F menunjukkan bahwa nilai signifikan dari 3 variabel bebas yaitu variabel kepemimpinan otokratis (X1), lingkungan kerja (X2) dan konflik (X3) sebesar 0,000 dan F hitung 14,272. Hasil ini memperlihatkan bahwa variabel kepemimpinan otokratis (X1), lingkungan kerja (X2) dan konflik (X3) secara simultan berpengaruh signifikan terhadap stres kerja. Sehingga dapat disimpulkan bahwa dalam penelitian ini terdapat pengaruh signifikan antara variabel bebas terhadap stres kerja di PT Bintan Bersatu Apparel Batam. 
DIMENSI, VOL. 7, NO. $1: 121-146$

MARET 2018

ISSN: 2085-9996

\section{KESIMPULAN DAN SARAN}

\section{Kesimpulan}

Kesimpulan penelitian ini adalah sebagai berikut:

1. Kepemimpinan otokratis berpengaruh negatif dan signifikan terhadap stres kerja karyawan PT. Bintan Bersatu Apparel Batam, dinyatakan ditolak. Hal ini dibuktikan dengan nilai signifikansi sebesar 0,139>0,05 (nilai alpha).

2. Lingkungan kerja berpengaruh positif dan signifikan terhadap stres kerja karyawan PT. Bintan Bersatu Apparel Batam, dinyatakan diterima. Hal ini dibuktikan dengan nilai signifikansi sebesar 0,031<0,05 (nilai alpha).

3. Konflik berpengaruh positif dan signifikan terhadap stres kerja karyawan PT. Bintan Bersatu Apparel Batam, dinyatakan diterima. Hal ini dibuktikan dengan nilai signifikansi sebesar 0,000 < 0,05 (nilai alpha).

4. Kepemimpinan Otokratis, Lingkungan Kerja dan Konflik secara simultan berpengaruh signifikan terhadap stres kerja karyawan PT. Bintan Bersatu Apparel Batam. Hal ini dibuktikan dengan nilai signifikansi Uji F sebesar 0,000 < 0,05 (nilai alpha).

\section{Saran}

1. Manajemen PT. Bintan Bersatu Apparel di Kota Batam Lebih memperhatikan lingkungan kerja yang cenderung menimbulkan stress kerja dan konflik kerja.

2. Penelitian ini masih memiliki keterbatasan, yaitu alat analisis yang bisa dikembangkan menggunakan SEM (Structural Equation Model) sehingga dapat mengetahui hubungan antar variable lebih jelas.

3. Manajemen PT. Bintan Bersatu Apparel Batam hendaknya memberikan bimbingan dan konseling pada karyawannya sehingga mereka lebih nyaman bekerja.

\section{DAFTAR PUSTAKA}

Almasitoh, U. (2011). Stres Kerja Ditinjau dari Konflik Peran Ganda dan Dukungan Sosial pada Perawat. Journals of Management, 68-82.

Apriyanti, T. (2010). Pengaruh Konflik Kerja Terhadap Stres Kerja Karyawan Pada PT Indo Citra Mandiri Bandar Lampung. Journals of Management, 17. 
Arifin, S. (2013). Leadership (Ilmu dan Seni Kepemimpinan). Jakarta: Salemba Empat.

Ashrahenny dan Ratnasari, Sri Langgeng. 2016. Pengaruh Gaya Kepemimpinan Dan Komunikasi Terhadap Kinerja Karyawan PT. Hi-Test (Laboratory Of Mechanical Testing). Zona Manajemen ISSN 2087-6998. Fakultas Ekonomi Universitas Batam. Volume 8, Nomor 3, Desember 2016. Hal. 1-10

Bahua, N. (2014). Pengaruh Lingkungan Kerja Terhadap Stres Kerja Karyawan (Studi pada PT Bank SULU Cabang Gorontalo). Journals of Management, 19.

Burhanudin, A. (2015). Manajemen Sumber Daya Manusia Perusahaan. Yogyakarta: PT Remaja Rosdakarya.

Che Han, I Gusti Salit Ketut Netra. (2013). Pengaruh Konflik Terhadap Stres Kerja Dan Kepuasan Kerja Karyawan. Journals of Management, 2150-2166.

Darmayanti dan Ratnasari, Sri Langgeng. 2016. Pengaruh Gaya Kepemimpinan Dan Fasilitas Kerja Terhadap Kinerja Pegawai Pada Kantor Camat Batam Kota. Zona Manajemen ISSN 2087-6998. Fakultas Ekonomi Universitas Batam. Volume 8, Nomor 1, April 2016. Hal. 11-18

Danur Mega Pratiwi, Ratri Wahyuningtyas. (2015). Pengaruh Lingkungan Kerja Fisik Terhadap Stres Kerja Karyawan PT Krakatau Steel Persero (Tbk) Divisi CRM. Journals of Management, 1-10.

Efendi, Vivi Kusuma dan Ratnasari, Sri Langgeng. 2014. Pengaruh Kepemimpinan, Komunikasi, Dan Motivasi Kerja Terhadap Kinerja Guru SMA Di Kecamatan Batam Kota Batam. Zona Manajemen ISSN 2087-6998. Fakultas Ekonomi Universitas Batam. Volume 6, Nomor 3, Desember 2014. Hal. 1-13

Fahmi, I. (2011). Manajemen Kepemimpinan (Teori dan Aplikasi). Bandung: Alfabeta.

I Made Bagus Indra Dewa, I Wayan Mudiartha Utama. (2014). Pengaruh Komunikasi , Kepemimpinan dan Lingkungan Kerja Terhadap Stres Kerja Pegawai pada PD . Pasar Kota Singaraja Unit Pasar Anyar. Journals of Managements, 45-62.

Kartono, K. (2015). Pemimpin dan Kepemimpinan. Jakarta: Rajawali Pers.

Kartono, K. (2016). Pemimpin dan Kepemimpinan. Jakarta: Rajagrafindo Persada.

Mulyadi, D. (2015). Perilaku Organisasi dan Kepemimpinan Layanan. Bandung: Alfabeta. 
DIMENSI, VOL. 7, NO. $1: 121-146$

MARET 2018

ISSN: 2085-9996

Lilo, Christianto dan Sri Langgeng Ratnasari. (2015). Pengaruh Gaya Kepemimpinan Dan Kompensasi Terhadap Kinerja Karyawan Pada PT. Supreme Nusapermai Development. Zona Manajerial. ISSN 2087-7331. Volume 7 Nomor 2, Agustus 2015. Hal. 50-69. Fakultas Ekonomi Universitas Batam

Murwanto, Didik dan Sri Langgeng Ratnasari. (2016). Pengaruh Kompensasi dan Gaya Kepemimpinan Terhadap Motivasi Kerja Karyawan PT. Fast Precision Manufacturing Indonesia. Zona Manajerial. ISSN 2087-7331. Volume 8 Nomor 1, April 2016. Hal. 112. Fakultas Ekonomi Universitas Batam

Ratnasari, Sri Langgeng dan Gandhi Sutjahjo. (2017). Pengaruh Kepemimpinan Transformasional Dan Lingkungan Kerja Terhadap Semangat Kerja Tenaga Kependidikan. Jurnal Inspirasi Bisnis \& Manajemen. Vol 1, (2), 2017. Hal. 99-112.

Saputro, Andi dan Ratnasari, Sri Langgeng. 2014. Pengaruh Kepemimpinan dan Motivasi Kerja Terhadap Kinerja Karyawan PT. Giken Pricision Indonesia. Zona Manajerial ISSN 2087-7331. Volume 6 Nomor 3, Desember 2014. Fakultas Ekonomi Universitas Batam. Hal. 1-12.

Sambas Ali Muhidin, Maman Abdurahman. (2007). Analisis Korelasi, Regresi dan Jalur. Bandung: CV Pustaka Setia.

Sanusi, A. (2011). Metodologi Penelitian Bisnis. Jakarta: Salemba Empat.

Sedarmayanti. (2011). Tata Kerja dan Produktivitas Kerja. Bandung: CV Mandar Maju. Sugiyono. (2014). Metode Penelitian Kuantitatif, Kualitatif dan R\&D. Bandung: Alfabeta.

Sujarweni, V. W. (2014). Metodologi Penelitian. Yogyakarta: PT Pustaka Baru.

Sunyoto, D. (2013). Perilaku Organisasional. Yogyakarta: Centre for Academic Publishing Service.

Sutrisno, E. (2009). Manajemen Sumber Daya Manusia. Jakarta: PrenadaMedia Group.

Veliana Sutanto, Jesslyn Angelina Mogi. (16). Analisa Pengaruh Work Family Conflict Terhadap Stres Kerja dan Kinerja Karyawan di Restoran The Duck King Imperial Chef Galaxy Mall Surabaya. Journals of Management, 377-391.

Waluyo, M. (2012). Manajemen Psikologi Industri. Jakarta: Indeks. 
Wasla, Elvina dan Ratnasari, Sri Langgeng. Pengaruh Gaya Kepemimpinan Dan Motivasi Terhadap Kinerja Karyawan PT. Citra Pembina Pengangkutan Industries Batam. EKSEKUTIF Jurnal Nasional Manajemen Bisnis Volume 13, Nomor 1, Juni 2016 ISSN: 1829-7501 Hal. 97-111

Wibowo, A. E. (2012). Aplikasi Praktis SPSS dalam Penelitian. Yogyakarta: Gava Media.

Wicaksono, Bayu Dimas dan Sri Langgeng Ratnasari. 2017. Determinasi Komunikasi, Motivasi, Dan Lingkungan Kerja Terhadap Kinerja Karyawan Di Perusahaan Umum (Perum) Bulog Sub Divre Kota Batam. Jurnal Bening. Vol. 4. No. 1. 2017. ISSN: 225252672.

Wiranata, A. A. (2011). Pengaruh Kepemimpinan Terhadap Kinerja dan Stres Karyawan (Studi Kasus: CV. Mertanadi). Journals of Management, 155-160.

Zainudin dan Sri Langgeng Ratnasari. (2015). Pengaruh Gaya Kepemimpinan, Lingkungan Kerja, Dan Motivasi Terhadap Kinerja Guru Sekolah Dasar Kecamatan Batu Ampar Kota Batam. Zona Manajemen. ISSN: 2087-6998. Batam: Fakultas Ekonomi Universitas Batam. Vol. 7, No.3. Desember 2017. 